\title{
PENGAWASAN TERINTEGRASI TERHADAP KAMPANYE PREMATUR PETAHANA DALAM PEMILIHAN KEPALA DAERAH
}

\author{
Muhamad Saleh \\ Pusat Studi Hukum Konstitusi \\ Fakultas Hukum Universitas Islam Indonesia, \\ Yogyakarta, Indonesia, \\ muhammadsalehlaw@gmail.com \\ Sahid Hadi \\ Pusat Studi Hak Asasi Manusia \\ Universitas Islam Indonesia \\ Mahasiswa Magister Hukum, \\ Fakultas Hukum Universitas Islam Indonesia, \\ Yogyakarta, Indonesia \\ sahidhadi8@gmail.com
}

\begin{abstract}
This article is written on two objects of study. First, what are the conceptual, normative, and institutional problems in the supervision of the incumbent's premature campaign in a Local Election? Second, how is the idea of an integrated design to supervise the premature campaign of the incumbent? This normative research is conducted using a case, conceptual, and statutory approach. The finding of this study is that the premature campaign has not been strictly regulated by the Election Law. The absence of a strict regulation means that the incumbent's premature campaign can be interpreted using various regulations so that the ambiguity of the supervisory institution existed in this case. Therefore, integrated supervision is offered. Integrated supervision in this context provides a formal coordination forum among supervisory agencies, consisting of representatives from the supervision of the ethical regime, government, public services, law enforcement, with the Bawaslu as the coordinator.
\end{abstract}

Keywords: Incumbent, Integrated Supervision, Premature Campaign 


\section{Abstrak}

Artikel ini ditulis atas dasar dua objek kajian. Pertama, apa problematik konsepsional, aturan normatif, dan kelembagaan dalam pengawasan terhadap kampanye prematur petahana dalam Pilkada? Kedua, bagaimana gagasan desain pengawasan terintegrasi untuk mengawasi kampanye prematur petahana? Untuk itu, penelitian normatif ini dilakukan dengan pendekatan kasus, konseptual, dan perundang-undangan. Temuan dari penelitian ini adalah bahwa kampanye prematur belum diatur secara tegas oleh undang-undang tentang Pilkada. Ketiadaan aturan yang tegas ini menyebabkan tindakan kampanye prematur yang dilakukan petahana dapat ditafsirkan menggunakan berbagai peraturan sehingga ambiguitas lembaga pengawasan terjadi dalam hal ini. Karenanya, pengawasan terintegrasi dirumuskan sebagai jawaban atas persebaran aturan dan kelembagaan yang mengawasi kampanye prematur petahana. Pengawasan terintegrasi dalam konteks ini menyediakan forum koordinasi formal antarlembaga pengawas, yang terdiri dari perwakilan dari pengawasan pada rezim etik (DKPP), pemerintahan (APIP), pelayanan publik (Ombudsman), penegakan hukum (Kepolisian, Kejaksaan, dan KPK), dengan Bawaslu sebagai koordinatornya.

Kata Kunci: Kampanye Prematur, Petahana, Pengawasan Terintegrasi

\section{Pendahuluan}

Salah satu politik hukum penyelenggaraan Pemilihan Kepala Darah (Pilkada) di Indonesia adalah dimungkinkannya petahana (gubernur, bupati, atau wali kota) untuk mencalonkan diri sebagai kepala daerah untuk kedua kalinya. Dalam hal pelaksanaan kampanye, calon petahana memiliki posisi yang berbeda dari calon lain karenanya. Menurut Scott Ashworth, ada dua alasan untuk perbedaan ini. Pertama, terhadap petahana, ada pilihan yang dapat dinilai dan dibandingkan dengan calon lain. Kedua, dibandingkan penantang atau calon non-petahana, calon petahana berpeluang lebih dulu meyakinkan pemilih ketika menyelenggarakan pemerintahannya (2006). Peluang untuk lebih dulu meyakinkan pemilih membuka celah bagi petahana untuk memanfaatkan jabatan. Dalam praktiknya, ini dapat berupa pemanfaatan fasilitas dan anggaran negara, pemobilisasian Aparatur Sipil Negara (ASN), pemanfaatan diskresi dan keputusan, personal branding, dan kampanye di luar jadwal.

Pembentuk

undang-undang manyadari potensi masalah di atas. Sejumlah pembatasan bagi petahana diberlakukan karenanya. Pasal 70 ayat (3) dan Pasal 71 ayat (2) dan (3) Undang-Undang Nomor 10 Tahun 2016 tentang Perubahan Kedua atas Undang-Undang Nomor 1 Tahun 2015 tentang Penetapan Peraturan Pemerintah Pengganti UndangUndang Nomor 1 Tahun 2014 tentang Pemilihan Gubernur, Bupati, dan Walikota Menjadi Undang-Undang (UU Pilkada) dalam hal ini mengatur 
petahana (i) wajib menjalankan cuti di luar tanggungan negara dan (ii) dilarang menggunakan fasilitas negara yang terkait dengan jabatan, melakukan penggantian pejabat enam bulan sebelum tanggal penetapan pasangan calon, serta menggunakan kewenangan, program, dan kegiatan yang menguntungkan atau merugikan calon lain. Hanya saja, pembatasan ini memiliki kelemahan yang salah satunya terkait dengan pengawasan penyelenggaraan kampanye.

Kelemahan dimaksud tercermin misalnya dari kampanye Bupati Klaten dan Walikota serta Wakil Walikota Semarang melalui penyaluran bantuan sosial (bansos) penanganan Covid-19, yang tindakan ini dilakukan dalam rangka mencalonkan diri kembali pada Pilkada 2020 (Nugraheny, 2020). Selain itu, ada juga kasus curi start kampanye oleh Aparatur Sipil Negara (ASN) yang hendak menjadi calon kepala daerah di Kabupaten Gunung Kidul (Awalani, 2020).

Kasus-kasus di atas memang tampak seperti "kampanye di luar jadwal." Namun, rumusan "kampanye di luar jadwal" yang diatur dalam Pasal 69 huruf k UU Pilkada sesungguhnya belum mampu mengantisipasi kasuskasus di atas. Pasalnya, kampanye di luar jadwal, termasuk ketentuan pidana Pasal 187 UU Pilkada, hanya berlaku bagi "calon kepala daerah" yang telah ditetapkan sebagai calon serta waktunya mengacu pada masa kampanye yang ditetapkan Komisi Pemilihan Umum (KPU). Ketentuan yang terpaku pada proses tahapan dan waktu ini nyatanya dapat dimanfaatkan oleh petahana yang memiliki kepentingan elektoral dengan melakukan kampanye sebelum penetapannya sebagai calon dilakukan; kampanye prematur.

Bawaslu, lembagayang berwenang mengawasi penyelenggaraan Pilkada, tidak dapat secara ketat mengawasi tindakan kampanye ini. Sebab, kampanye demikian tidak tergolong "kampanye" dan "kampanye di luar jadwal" sebagaimana ditetapkan UU Pilkada. Ini sesungguhnya dengan gamblang menunjukkan ada persoalan serius dalam penyelenggaraan pengawasan terhadap petahana yang melakukan kampanye-kampanye prematur, sebagaimana kasus-kasus yang disebutkan pada paragraf sebelumnya.

Persoalan di atas semakin mencemaskan pada tataran praktis. Sebab, Bawaslu melalui Indeks Kerawanan Pemilu (IKP) Pilkada Serentak 2020, khususnya dalam temuan terkait dimensi kontestasi yang terdiri dari sub-dimensi pelanggaran kampanye, politik uang kepada pemilih, dan penyalahgunaan fasilitas negara, menyimpulkan bahwa Pilkada serentak 2020 memiliki tingkat kerawanan yang cukup diwaspdai. Bawaslu memberi skor $62,52 \%$ untuk kampanye di luar jadwal sehingga ini memang rawan terjadi (Bawaslu, 2020, hlm. 39).

Dengan demikian, mengkaji secara lebih lanjut persoalan pengawasan terhadap kampanye di luar jadwal, yang penetapan calon belum dilakukan, menjadi penting dilakukan. Karenanya, berdasarkan sekelumit masalah di atas, ada dua pertanyaan pokok yang akan dijawab. Pertama, apa problematik aturan normatif dan kelembagaan dalam 
pengawasan terhadap kampanye prematur petahana dalam Pilkada? Kedua, bagaimana gagasan desain pengawasan terintegrasi untuk mengawasi kampanye prematur petahana?

\section{Metode Penelitian}

Penelitian normatif ini menggunakan pendekatan kasus, konseptual, dan perundang-undangan untuk menyajikan jawaban atas dua rumusan masalah di atas. Pendekatan kasus dipilih untuk memberi ilustrasi sehubungan dengan fenomena kampanye prematur petahana, salah satunya merujuk ke kasus kampanye prematur di Klaten melalui bansos penanggulangan pandemi Covid-19. Dengan pendekatan konseptual, konsep keadilan elektoral dan pengawasan digunakan. Pendekatan perundang-undangan dipilih untuk mengungkap faktor hukum positif sebagai penyebab adanya problematik pengawasan kampanye prematur petahana. Pada saat yang sama, pendekatan perundang-undangan juga menjadi basis legalitas dalam mendesain konsep pengawasan terintegrasi.

Jenis data yang dikumpulkan adalah data-data kualitatif berupa data sekunder yang dikumpulkan menggunakan teknik studi kepustakaan. Ini berupa (i) bahan hukum primer dan (ii) bahan hukum sekunder yang bersumber dari buku, jurnal, dan pemberitaan yang diperoleh dari dokumen-dokumen berbasis online dan dicetak secara fisikal.

\section{Konsep Keadilan Elektoral dan Pengawasan}

\subsection{Konsep Keadilan Elektoral}

Pilkada diselenggarakan secara demokratis. Pasal 18 ayat (4) UUD NRI 1945 dasarnya. Pilkada yang demokratis sepatutnya berada dalam kerangka agung lima sila, yang salah satunya menuntun supaya Pilkada diselenggarakan atas dasar nalar kemanusiaan, berkeadilan, dan berkeadaban. Karenanya, sebuah modalitas yang menjembatani dari norma "Pilkada yang demokratis" ke telos "penyelenggaraan yang pararel dengan ide kemanusiaan yang adil dan beradab" dibutuhkan. Dalam hal ini, The International Institute for Democracy and Electoral Assistance (International IDEA) mengintrodusir konsep keadilan elektoral.

Keadilan elektoral merupakan sebuah mekanisme untuk menjaga keteraturan proses elektoral (Orozco-Henriquez, 2010, hlm. 9). Ini melingkupi (i) upaya pencegahan terhadap pelanggaran dalam putaran elektoral, mulai dari pre-electoral, electoral period, hingga post-electoral, dan (ii) mekanisme pemulihan bila pelanggaran dalam proses elektoral tetap terjadi (Nkansah, 2016, hlm. 100).

Keadilan elektoral mencegah dan mengidentifikasi ketidakteraturan dalam Pilkada. Ini mulai dari membenahi ketidakberesan dalam putaran hingga mengaktifkan mekanisme penjatuhan sanksi bagi pelaku yang melanggar peraturan dan hak orang lain (Jurnaidi, 2013). 
Mekanisme ini juga mendorong agar Pilkada dipahami secara universal dan terbuka serta menyoroti secara menyeluruh setiap unsur yang ada. Tujuannya adalah memastikan Pilkada yang demokratis dapat terselenggara (Jurnaidi, 2013). Pada titik ini, perspektif keadilan elektoral menujukkan urgensi perannya.

Fritz Edward Siregar menyebut keadilan elektoral sebagai garansi utama dari pelaksanaan prinsip demokrasi dan kunci dari negara hukum guna menjaga kebebasan dan keadilan pemilihan (Siregar, 2019, hlm. 298). Rahmat Bagja juga menyebut keadilan elektoral sebagai elemen kunci kredibilitas proses elektoral. Ini karena, pertama, mekanisme keadilan elektoral menjamin setiap tindakan, prosedur, dan keputusan sehubungan dengan proses pemilihan sesuai dengan kerangka hukum dan hak asasi manusia. Kedua, mekanisme ini juga melindungi dan memulihkan hak elektoral; hak memilih dan dipilih. Ketiga, mekanisme ini memungkinkan setiap orang yang merasa hak elektoralnya dilanggar untuk mengajukan pengaduan, mengikuti persidangan, hingga mendapatkan putusan. Dalam hal ini, keadilan elektoral tidak hanya terbatas pada aspek penegakan hukum, namun juga merupakan salah satu faktor penting dalam merancang dan menjalankan proses elektoral, tak ubahnya Pilkada (Siregar, 2019, hlm. 298).

$$
\text { Proses }
$$
elektoral

yang

berintegritas, partisipatoris, berdasarkan rule of law, imparsial, profesional, independen, transparansi, terukur dari segi waktu, tidak melanggar hak dan ketentuan perundang-undangan, dan diterima secara meluas menjadi konsekuensi dari aktifnya keadilan elektoral (Nkansah, 2016, hlm. 100). Di samping itu, keadilan elektoral bila dilihat dengan kaca mata hak asasi manusia tidak hanya berfungsi sebagai wadah untuk menyelesaikan sengketasengketa elektoral, melainkan juga untuk melindungi hak politik dan hak pilih dari warga negara (Siregar, 2019, hlm. 298). Domenico Tuccinardi bahkan dengan yakin menuturkan, keadilan elektoral penting guna mencegah konflik elektoral (2011).

Keadilan elektoral mewujud dalam berbagai bentuk, mengingat gejala sosial-politik di setiap negara berbeda-beda. Hanya saja, ia memiliki sebuah tujuan utama; mempersembahkan jaminan tertinggi untuk proses elektoral yang "free, fair and genuine." Namun demikian, perspektif keadilan elektoral memang tidak menjamin secara pasti proses pemilihan yang free, fair and genuine itu. Sayangnya, ketiadaan perspektif ini beserta prinsip-prinsip penyelenggarannya juga berpotensi membuat konflik dan sengketa elektoral menjadi lebih parah dan lebih buruk (Orozco-Henriquez, 2010, hlm.2-3).

\subsection{Konsep Pengawasan}

Pengawasan menurut Lyndal $F$. Urwick merupakan sebuah upaya agar sesuatu dilaksanakan sesuai peraturan dan instruksi yang ditetapkan. George R. Terry mengatakan, pengawasan merupakan proses penentuan untuk (i) suatu capaian berupa standar, (ii) sesuatu yang dilakukan berupa menilai pelaksanaan, dan bila perlu 
(iii) melakukan perbaikan tertentu sehingga pelaksanaan sesuai dengan rencana (Tjandra, 2014, hlm. 23).

Pengawasan merupakan bagian dari penegakan hukum dalam perspektif hukum administrasi negara. Penegakan hukum menjadi bagian dari kekuasaan untuk memerintah (besturen). Karenanya, pengawasan tunduk pada asas-asas umum terkait hukum pemerintahan; asas keabsahan (rechtmatigheid van bestuur), efektivitas dan efisiensi (doelmatigheid en doeltreffendheid), keterbukaan

(openbaarheid van bestuur), dan berencana (planmatigheid) (Philipus M. Hadjon, 1996:335). Maka dari itu, menurut P. Nicolas dan kawan-kawan (HR, 2016, $\mathrm{hlm}$. 296), pengawasan ialah sarana penegakan hukum administrasi. Pengawasan memastikan organ pemerintahan taat dan bertindak berdasarkan peraturan.

Pengawasan juga melingkupi wewenang untuk menerapkan sanksi pemerintahan. Ini senanda dengan J.B.J.M. ten Berge (Sembiring, 2009, $\mathrm{h} / \mathrm{m}$. 178) yang menyebut instrumen penegakan hukum administrasi meliputi dua hal, yaitu pengawasan dan penegakan sanksi. Pengawasan merupakan langkah preventif untuk memaksa kepatuhan, sedangkan penerapan sanksi merupakan langkah represif untuk memaksa kepatuhan.

Pengawasan menurut Paul E. Lotulung dapat juga ditinjau dari segi objek yang diawasi. Ini berupa kontrol dari segi hukum dan kemanfaatan. Dari segi hukum, kontrol dimaksudkan untuk menilai kebenaran perbuatan pemerintah dengan berbasis pada hukumnya saja, yaitu dari segi rechtmatigheid dari perbuatan pemerintah. Dari segi kemanfaatan, ini dimaksudkan untuk menilai kebenaran perbuatan pemerintah dari segi atau pertimbangan kemanfaatanya (HR, 2016, hlm. 297).

\section{Problematik Aturan Normatif dan Kelembagaan Pengawasan \\ Kampanye Prematur Petahana dalam Pilkada}

\subsection{Kampanye Prematur: Sebuah Batasan Konsepsional}

Kampanye merupakan "core feature" dan "essential supplement" dalam Pilkada. Kampanye dapat memengaruhi preferensi politik dan memobilisasi dukungan publik (Schmitt, 2002, hlm. 1-2). Kampanye karenanya diyakini mampu memengaruhi proses pengambilan keputusan dari seseorang atau suatu kelompok (Fatimah, 2018, hlm. 7-8). Itulah sebabnya, kampanye berdasarkan Pasal 1 angka 21 UU Pilkada merujuk ke "kegiatan untuk meyakinkan pemilih."

"Kegiatan untuk meyakinkan pemilih" sesungguhnya membuat kampanye dimaknai atas dasar tujuan atau akibat yang ditimbulkannya; meyakinkan pemilih. Ini pararel dengan penjelasan Rice dan Paisley, bahwa kampanye "seems to represent someone's intention to influence someone's beliefs or behavior" (Rice dan Paisley, 1981, hlm. 23). Namun, UU Pilkada ternyata tidak memaknai kampanye berdasarkan tujuan atau akibatnya saja.

UU Pilkada juga membatasi pemaknaan kampenye dengan 
kerangka penafisran yang lain. Ini merujuk ke Pasal 5 ayat (1) dan (3), Pasal 63 ayat (3), dan Pasal 67 ayat (1) UU Pilkada. Pasal-pasal tersebut menjadikan pemaknaan kampanye dispesialisasi pada setiap kegiatan untuk meyakinkan pemilih yang dilakukan dalam rentang waktu yang telah ditentukan KPU. Ini sama dengan pemaknaan dari Rogers dan Storey, bahwa kampanye merupakan kegiatan terencana yang dilakukan secara terus-menerus dan dalam waktu yang spesifik untuk menciptakan akibat, efek, atau outcome tertentu. Hanya saja, pemaknaan ini telah dipandang usang belakangan, terutama oleh D. Lawrence Kincaid, Richard Delate, Douglas Storey, dan Maria Elena Figueroa misalnya (Rice dan Atkin, 2013, hlm. 521).

Spesialisasi makna ini tentu saja mengandung celah berbahaya. Pasalnya, kegiatan-kegiatan yang dengan sengaja dilakukan untuk memengaruhi preferensi politik, memobilisasi dukungan publik, dan/ atau meyakinkan pemilih tidak akan pernah tergolong kampanye bila dilakukan di luar rentang waktu yang sah, termasuk ketika dilakukan secara prematur.

Kampanye prematur dimaksud berbeda dari "kampanye di luar jadwal" sebagaimana diatur UU Pilkada. Berdasarkan Pasal 69 huruf k dan Pasal 187 UU Pilkada, kampanye di luar jadwal ialah kampanye "masingmasing calon" di luar jadwal yang telah ditetapkan KPU. Calon kepala daerah, baik petahana maupun non-petahana, telah ditetapkan dalam konteks ini. Karenanya, kampanye yang dilakukan di luar jadwal namun belum ada penetapan calon sesungguhnya tidak tergolong "kampanye di luar jadwal" sebagaimana diatur UU Pilkada.

Kampanye prematur dengan demikian merujuk ke setiap kegiatan untuk memengaruhi preferensi politik, memobilisasi dukungan publik, dan/atau meyakinkan pemilih yang dilakukan di luar jadwal yang telah ditetapkan namun penetapan calon belum dilakukan.

Sebagai ilustrasi, pada konteks Pilkada serentak 2020, penetapan pasangan calon dilakukan pada 23 September 2020 dan masa kampanye ditetapkan pada 26 September hingga 5 Desember 2020 berdasarkan Peraturan KPU Nomor 5 Tahun 2020 tentang Perubahan Ketiga atas Peraturan KPU Nomor 15 Tahun 2019 tentang Tahapan, Program, dan Jadwal Penyelenggaraan Pemilihan Gubernur dan Wakil Gubernur, Bupati dan Wakil Bupati, dan/atau Wali Kota dan Wakil Wali Kota Tahun 2020. Bila merujuk ke larangan kampanye di luar jadwal sebagaimana diatur UU Pilkada, maka larangan Pasal 69 huruf $k$ dan sanksi Pasal 187 UU Pilkada hanya dapat diterapkan untuk kegiatan kampanye yang dilakukan pada 23 hingga 26 September 2020. Kampanye prematur justru dilakukan sebelum 23 September 2020.

Kampanye prematur petahana nyata adanya. Secara kasuistis, ini terjadi dalam penyaluran bansos penanganan Covid-19, sebagaimana dilakukan Bupati Klaten dan Walikota serta Wakil Walikota Semarang dalam rangka mencalonkan diri kembali pada Pilkada 2020. Tindakan ini dilakukan melalui tiga modus. Pertama, bansos dikemas dan dilabeli gambar petahana. 
Kedua, bansos yang didistribusikan dikemas dengan menyertakan jargon kampanye dan simbol-simbol politik daripetahana. Ketiga, bansos diberikan tidak mengatasnamakan pemerintah, tetapi atas nama petahana secara pribadi (Nugraheny, 2020).

\subsection{Mengawasi Kampanye Prematur Petahana: Problem Aturan dan Ambiguitas Lembaga Pengawas}

Praktik kampanye prematur tidak hanya memiliki persoalan konsepsional, sebagaimana telah Penulis identifikasi pada sub-bab 4.1. Namun, terdapat juga persoalan lain yang merujuk ke problem aturan dan ambiguitas lembaga pengawas, di antaranya, pertama, pengawasan kampanye prematur petahana dan UU Pilkada. Kampanye prematur sesungguhnya belum secara spesifik diatur dalam UU Pilkada. Ketentuan UU Pilkada tentang "kampanye di luar jadwal" hanya dapat diberlakukan ketika penetapancalon telah dilakukan, sedangkan kegiatan petahana yang tergolong kampanye prematur terjadi sebelum calon ditetapkan.

Bawaslu tidak dapat menjangkau kampanye jenis ini. Fitur pengawasan Bawaslu pasalnya baru dapat digunakan setelah penetapan calon dilakukan. Walau begitu, bila basis pengawasan dititikberatkan pada akibat-akibat yang ditimbulkan dari kampanye prematur, mobilisasi pemilih misalnya, maka ketentuan pidana Pasal 71 ayat (3) jo. Pasal 188 UU Pilkada dapat digunakan. Jadi, UU Pilkada dalam hal ini menghendaki lembaga penegak hukum seperti Kepolisian, Kejaksaan, Pengadilan, dan Lembaga Pemasyarakatan yang mengawasi petahana agar tidak melakukan tindakan yang bernuansa kampanye prematur.

Kedua, pengawasan kampanye prematur petahana dan UU Pemda. Kampanye prematur petahana dilakukan dalam kapasitasnya sebagai kepala daerah, bukan calon kepala daerah. Ini penting untuk diperhatikan. Sayangnya, UU Pemda tidak mengatur secara eksplisit ketentuan tentang kampanye prematur ini. Namun, tidak ada yang keliru dengan ketiadaan aturan tersebut. Pasalnya, UU Pemda merupakan seperangkat aturan tentang penyelenggaraan pemerintahan daerah, bukan kampanye dan ke-Pilkada-an.

Kampanye prematur petahana sebagai tindakan kepala daerah dalam penyelenggaraan pemerintahan dengan demikian turut menjadi objek pengawasan di bawah naungan UU Pemda. Dalam hal ini, UU Pemda sesungguhnya memiliki pasal-pasal yang dapat digunakan sebagai instrumen pengawasan terhadap tindakan pemanfaatan jabatan demi kepentingan elektoral ini.

Bila kampanye prematur petahana tergolong penyalahgunaan wewenang yang menguntungkan diri sendiri, maka Pasal 76 huruf d UU Pemda secara jelas dan tegas melarang dilakukannya kampanye prematur. Unsur "menguntungkan diri sendiri" pada pasal tersebut terpenuhi atas dasar akibat yang ditimbulkan dari kampanye prematur, yang mengarah ke pengaruh preferensi politik, mobilisasi dukungan publik, dan/atau meyakinkan pemilih. Pasal 78 ayat (1) huruf c jo. ayat (2) huruf 
e UU Pemda dalam hal ini mengatur sanksi administratif bagi petahana yang melanggar ketentuan di atas, yaitu diberhentikan. Kampanye prematur petahana dengan demikian tidak dipandang sebagai tindak pidana berdasarkan UU Pemda. Merujuk ke Pasal 7 jo. Pasal 377 UU Pemda, penyalahgunaan wewenang demikian diawasi oleh Aparat Pengawas Internal Pemerintah (APIP).

Bila kampanye prematur petahana tergolong pemanfaatan jabatan yang menguntungkan diri sendiri, maka APIP merupakan lembaga pengawasnya. Selain karena UU Pemda tidak merumuskan secara tertulis dan pasti tindak pidana tentang kampanye prematur atau pemanfaatan jawaban, Pasal 10 ayat (2) Peraturan Pemerintah Nomor 12 Tahun 2017 tentang Pembinaan dan Pengawasan Penyelenggaraan Pemerintahan Dearah telah mengatur ruang lingkup pengawasan APIP terhadap penyelenggaraan pemerintahan daerah, yang wewenang itu sesungguhnya meliputi dilakukannya kampanye prematur.

Berbeda dari UU Pilkada, UU Pemda membuka peluang bagi APIP untuk melakukan pengawasan terhadap kampanye prematur petahana karena tindakan ini tergolong pelanggaran administratif.

Ketiga, pengawasan kampanye prematur petahana dan UndangUndang Nomor 24 Tahun 2007 tentang Penanggulangan Bencana (UU Penanggulangan Bencana). Kampanye prematur petahana juga dapat menjadi objek pengawasan berdasarkan UU Penanggulangan Bencana. Ini merujuk ke kampanye prematur dalam konteks pengelolaan sumber daya bantuan bencana yang diselenggarakan oleh pemerintah daerah. Petahana yang "menyalahgunakan pengelolaan sumber daya bantuan bencana" untuk urusan kampanye prematur bisa diancam berdasarkan Pasal 78 UU Penanggulangan Bencana dengan pidana penjara dan denda. UU Penanggulangan Bencana memberikan keleluasaan bagi lembaga penegak hukum untuk mengawasi penyalahgunaan pengelolaan sumber daya bantuan bencana petahana untuk kepentingan elektoralnya. UU Penanggulangan Bencana pararel dengan UU Pilkada; kampanye prematur petahana dapat tergolong tindak pidana.

Keempat, pengawasan kampanye prematur petahana dan UndangUndang Nomor 25 Tahun 2009 tentang Pelayanan Publik (UU Pelayanan Publik). Kampanye prematur petahana ternyata juga dapat diawasi berdasarkan UU Pelayanan Publik. Setiap kegiatan atau program petahana dalam rangka pemenuhan kebutuhan pelayanan dapat disalahgunakan untuk kepentingan kampanye prematur. Potensi ini disadari oleh pembuat undang-undang. Itulah sebabnya, Pasal 34 huruf $k$ dan $m$ UU Pelayanan Publik mengatur agar petahana "tidak menyalahgunakan sarana dan prasarana serta fasilitas pelayanan publik" dan "tidak menyalagunakan informasi, jabatan, dan/atau kewenangan yang dimiliki" untuk kepentingan pribadi.

UU Pelayanan Publik, dalam rangka mencegah tidak ditaatinya aturan di atas, mengatur maksnisme pengawasan melalui Pasal 35 UU 
Pelayanan Publik. Selain pengawasan internal, diselenggarakan oleh atasan langsung dari petahana dan pengawas fungsional, UU Pelayanan Publik memungkinkan masyarakat dan Ombudsman mengawasi ada tidaknya kampanye prematur yang dilakukan petahana melalui pelayanan publik.

Bila empat undang-undang di atas menjadi acuan minimum untuk menjawab fenomena kampanye prematur petahana, maka tindakan itu secara jelas tidak hanya menjadi persoalan di bidang ke-Pilkada-an saja secara an sich namun juga bidangbidang lain seperti penyelenggaraan pemerintahan daerah, penanggulangan bencana, hingga pelayanan publik. Jadi, setidaknya dua masalah mekanisme pengawasan terhadap kampanye prematur petahana terkuak, di antaranya:

- undang-undang yang secara tegas dan spesifik mengatur "kampanye prematur petahana" sesungguhnya belum ada, kendati ini pada tataran praktis dilakukan demi kepentingan elektoral petahana. Walau begitu, secara tersebar dan parsial, kampanye prematur setidak-tidaknya dapat disorot menggunakan kaca mata UU Pilkada, UU Pemda, UU Penanggulangan Bencana, dan UU Pelayanan Publik;

- terdapat amat banyak lembaga yang terlibat dalam mekanisme pengawasan terhadap kampanye prematur petahana. Pengawasan dapat dilakukan oleh APIP, Ombudsman, dan aparat penegak hukum seperti Kepolisian, Kejaksaan, dan Pengadilan. Lembaga-lembaga ini pada saat yang bersamaan memiliki wewenang pengawasan untuk objek yang sama yaitu kampanye prematur petahana.

\section{Desain Pengawasan Terintegrasi untuk Mengawasi Kampanye Prematur Petahana}

Persoalan lain sebagai derivasi dari dapat berlakunya empat undangundang tersebut adalah koordinasi yang buruk antarlembaga yang dapat mengawasi kampanye prematur. Banyaknya lembaga yang dapat terlibat dalam pengawasan tidak diwadahi dengan sebuah ketentuan atau pemandu tentang koordinasi antarlembaga. Masalah koordinasi ini terlihat dari, pertama, sulitnya Bawaslu menindak petahana yang melakukan kampanye prematur seperti memasang baliho dengan simbol-simbol individu pada berbagai program pemerintah di berbagai lokasi pemerintahan. Namun demikian, bila tindakan ini dipandang sebagai tindakan pemerintah daerah, Bawaslu sesungguhnya bisa saja berkoordinasi dengan APIP misalnya.

Kedua, sehubungan dengan pemanfaatan keuangan negara yang tidak dapat diawasi oleh penyelenggara Pilkada. Sebuah temuan menunjukan tren alokasi program dana bansos yang mengalami kenaikan pada daerah dengan calon kepada daerah petaha. Ini misalkan terjadi di Jawa Tegah. Berdasarkan Anggaran Pendapatan dan Belanda Daerah (APBD) 2018, alokasi bansos dan hibah dianggarkan sebesar Rp.5,6 triliun. Ironisnya, jumlah ini melebihi pagu bansos dan hibah pada APBD-P 
2017, Rp5,34 triliun dan APBD-P 2016, Rp5,35 triliun (Jay Akbar, 2018). Hal lain misalnya, pengawasan dana bansos Covid-19 yang berpotensi disalahgunakan untuk kepentingan kampanye petahana. Untuk ini, pengawasan sesungguhnya dapat melibatkan aparat penegak hukum dengan mengacu pada ketentuan pidana dalam Pasal 78 jo. Pasal 65 UU Penanggulangan Bencana yang juga dapat dikoordinasikan dengan penyelenggara Pilkada.

UU Pilkada dalam hal ini mengenal berbagai jenis pelanggaran, mulai dari pelanggaran kode etik, administrasi, tindak pidana, sengketa pemilihan, dan sengketa tata usaha negara. Pelanggaran-pelanggaran ini ditangani oleh penyelenggara Pilkada dan lembaga-lembaga lain selain penyelenggara Pilkada; Kepolisian, Kejaksaan, hingga Pengadilan. Namun, problematik aturan normatif dan kelembagaan dalam mengawasi kampanye prematur petahana nyatanya membuat jangkauan UU Pilkada menjadi terbatas dalam menyoroti praktik ini.

Mendudukkan

pengawasan karenanya menjadi penting. Sebab, keberadaan rezim pengawasan untuk pelaksanaan tugas dan wewenang petahan yang berada di luar bidang ke-Pilkada-an secara jelas beririsan dengan fungsi pengawasan di bidang ke-Pilkadaan. Sayangnya, pengawasan ini tidak terkoordinasi secara baik. Koordinasi padahal menjadi faktor dominan atas keberhasilan suatu lembaga melaksanakan fungsi pengawasan. Kesukaran yang diprediksi oleh Van Poeltje seakan terbukti dengan ego sektoral yang dimiliki lembagalembaga pemerintah, yang terkesan "gengsi" untuk bekerjasama, meminta bantuan, atau bertanya ke lembagalembaga pemerintah lainnya. Masalah koordinasi dalam hal ini merujuk ke masalah kerjasama antar-lembaga dan pertalian lembaga-lembaga yang ada (Syarifudin, 1976, hlm. 67).

Koordinasi menurut Van Poeltje sangat penting dan besar artinya. Kebutuhan atas koordinasi merupakan akibat dari adanya kekuatan-kekuatan yang memancar dan hidup dalam lingkungan lembaga pemerintahan yang jumlah dan coraknya beragam, namun sering terlihat bahwa dalam penyelenggaraan tugasnya, lembagalembaga ini berlawanan antara satu sama lain (1953). Lemahnya koordinasi menimbulkan perbedaan presepsi dalam menegakan keadilan elektoral di Pilkada.

Pengawasan pada bidang Pilkada sesungguhnya dapat dimaknai lebih luas sebagaimana dikehendaki konsep keadilan elektoral. la tidak hanya terbatas pada tahapan-tahapan yang telah ditetapkan, namun instrumen pengawasan yang berada di luar bidang ke-Pilkada-an sesungguhnya juga melekat pada saat petahana melakukan kampanye prematur, khususnya terkait pengawasan sehubungan dengan pelaksanaan tugas dan wewenang petahana. Untuk ini, berdasarkan aturan normatif dan persebaran fungsi lembaga pengawasan seperti diuraikan pada sub-bab sebelumnya, terdapat beberapa rezim yang dapat terlibat dalam pengawasan kampanye prematur petahana. 


\subsection{Rezim Etik dan Kampanye Prematur Petahana}

Jika memerhatikan rumusan syarat untuk menjadi seorang kepala daerah sebagaimana diatur dalam Pasal 7 huruf a dan i UU Pilkada, maka secara prinsipil ada ketentuan sehubungan dengan aspek-aspek moral dan etika pengemban jabatan publik. Ini di antaranya merujuk ke syarat ketakwaan kepada Tuhan Yang Maha Esa (dimensi spiritualitas) yang bermakna ketauhidan. Ada juga syarat untuk tidak pernah melakukan perbuatan tercela. Selain itu, Pasal 67 huruf d UU Pemda juga telah memberikan dimensi moral kepada kepala daerah untuk menjaga etika dan norma dalam pelaksanaan urusan pemerintahan yang menjadi kewenangan daerah.

Etika kepala daerah dipahami sebagai prinsip-prinsip dasar dan nilai-nilai yang diakui dan diterima sebagai sesuatu yang mengatur dan mengendalikan serta menentukan kebaikan dan keburukan, termasuk dalam penyeleggaraan pemerintahan daerah. Etika tersebut terdiri dari kejujuran, keadilan, tepat janji, taat aturan, hingga tanggung jawab. Sedangkan etika peserta Pilkada, ini nilainya bersumber dari etika politik dan etika kehidupan berbangsa dan bernegara di Indonesia. Kombinasi atas keberadaan etika kepala daerah dan etika peserta Pilkada artinya dibutuhkan untuk menjamin sinergitas antar-rezim pengawasan yang sesungguhnya saling beririsan itu.

Menegakan kode etik petahana dan peserta Pilkada urgen dilakukan setelah melihat sederet realitas dan dugaan perbuatan tidak etis yang dilakukan oleh peserta Pilkada, khususnya calon petahana. Pada subbab sebelumnya, jenis pelanggaran yang terjadi dalam tindakan kampanya prematur telah disampaikan, yaitu ia dapat dipandang sebagai pelanggaran administratif dan pidana, yang tentu saja dua pelanggaran ini secara otomatis merefleksikan adanya pelanggaran etis petahana, baik senagai kepala daerah maupun peserta Pilkada.

Kondisi lain yang mendorong penegakan dengan pendekatan etik adalah realitas penegakan hukum yang dirasa belum efektif dalam menangani kasus-kasus pelanggaran penyelenggara pemerintah oleh kepala daerah. Tahapan Pilkada pendek dan terbatas, sementara penanganan perkara melalui jalur hukum yang berlarut-larut sering kali mengacaukan penyelenggaraan Pilkada. Maka dari itu, penegakan kode etik dapat diandalkan untuk menangani kampanye prematur petahana (baik dalam konteks penyelenggaraan pemerintahan maupun ke-Pilkada-an). Ini karena prinsip penyelenggaraannya cepat, mudah, dan biaya ringan. Namun demikian, penegakan lewat jalur kode etik juga tidak menghentikan proses hukum yang berjalan. Mekanisme etik ini berguna untuk segera menetapkan status dari sang tertuduh; apakah bersalah atau tidak, sehingga tidak berlama-lama mengganggu tahapan dan jadwal Pilkada (Syarwani, 2016).

Kelembagaan etik di bidang Pemilu dan Pilkada untuk saat ini telah mengalami perkembangan dan 
modernisasi yang memadai. Salah satunya, dengan dihadirkannya DKPP, yang secara kewenangan dapat fokus pada penegakan etik penyelenggara Pilkada, peserta Pilkada (calon, partai politik, tim kampanye), sedangkan mekanisme penegakan etik untuk petahana yang maju kembali dapat mengikutsertakan lembaga penegak etik kepala daerah, komisi etik misalnya.

\subsection{Rezim}

Penyelenggaraan

Pemerintahan

Daerah

dan

Kampanye Prematur-Petahana

Penyelenggara

pemerintah

daerah mengenal mekanisme pengawasan yang dibentuk sebagai bagian dari pengawasan melekat dan berjenjang. Salah satu lembaga yang diberikan kewenangan untuk melakukan ini adalah APIP. APIP memiliki kewenangan melakukan pengawasan dan pembinaan atas pelaksanaan pemerintahan di tingkat daerah. Konteks pengawasan sekaligus pembinaan menjadikan APIP bukan hanya melakukan tindakan represif, melainkan juga preventif.

APIP dalam hal ini merupakan mitra pemerintah daerah. Perannya dapat berupa pengawas, konsultan, Quality Assurance (QA) dalam kegiatan operasional pemerintahan di pusat dan daerah. APIP diharapkan mampu mengendus setiap potensi penyimpangan atau korupsi serta melakukan deteksi dan pencegahan sejak dini untuk tindakan kampanye prematur petahana. Fungsi ini dapat juga menjadi early warning system dalam mencegah terjadinya korupsi (Marwata, 2017, hlm. 2).

APIP, yang termasuk Inspektorat di dalamnya, berdasarkan UU Pemda digolongkan sebagai bagian dari perangkat daerah provinsi, kabupaten, dan kota. Pengawasan penyelenggaraan pemerintah daerah yang dilakukan oleh APIP meliputi: (a) pembagian urusan pemerintahan; (b) kelembagaan daerah; (c) kepegawaian pada perangkat daerah; (d) keuangan daerah; (e) pembangunan daerah; (f) pelayanan publik di daerah; (g) kerja sama daerah; (h) kebijakan daerah; (i) kepala daerah dan DPRD; dan (j) bentuk pengawasan lain sesuai. Luasnya pelaksanaan pengawasan oleh APIP memperlihatkan kemungkinan adanya fitur APIP dalam mencegah pemanfaatan jabatan oleh petahana untuk kepentingan elektoral petahana melalui kampanye prematur. Karena praktik pemanfaatan jabatan oleh petahana lebih banyak bersinggungan dengan rezim pemerintahan daerah, koordinasi APIP dengan penyelenggara Pilkada menjadi hal yang perlu dilakukan.

\subsection{Rezim Pelayanan Publik dan Kampanye Prematur oleh Petahana}

Pasal 35 UU Pelayanan Publik mengatur, pengawasan penyelenggara pelayanan publik dilakukan oleh pengawas internal dan eksternal. Pengawasan internal dilakukan melalui pengawasan oleh atasan langsung dan oleh pengawas fungsional sesuai dengan peraturan perundangundangan. Sedangkan pengawasan eksternal dilakukan melalui pengawasan oleh masyarakat, ini dapat berupa laporan atau pengaduan masyarakat terkait penyelenggaraan pelayanan publik, pengawasan 
oleh Ombudsman sesuai dengan peraturan perundang-undangan, dan pengawasan oleh lembaga legislatif, baik pusat maupun daerah.

Pengawasan eksternal yang dilakukan oleh Obmudsman telah diatur melalui UndangUndang Nomor 37 Tahun 2008 tentang Ombudsman Republik Indonesia. Dalam undang-undang tersebut, Ombudsman adalah lembaga negara yang berfungsi mengawasi pelayanan publik yang diselenggarakan oleh penyelenggara negara dan pemerintahan yang sebagian atau seluruh dananya bersumber dari APBN/APBD, termasuk ketika pelaksana pelayanan publik (petahana) melakukan tindakan kampanye prematur. Mengacu pada kewenangan tersebut, pada posisi inilah keterlibatan dan koordinasi Ombudsman dalam mengawasi petahana yang akan maju Pilkada menjadi penting.

\subsection{Rezim Penegakan Hukum dan Kampanye Prematur Petahana}

Penegakan hukum meningkatkan ketertiban dan kepastian hukum dalam masyarakat sehingga, dalam konteks pengawasan, ini dapat mencegah terjadinya perbuatan yang bertentangan dengan hukum. Ini dilakukan antara lain dengan menertibkan tugas dan wewenang lembaga-lembaga menurut proporsi ruang lingkupnya masing-masing, serta didasarkan atas sistem kerjasama yang baik dan mendukung tujuan yang hendak dicapai (Sanyoto, 2008). Di Indonesia, berdasarkan Kitab UndangUndang Acara Pidana, yang termasuk dalam Criminal Justice System adalah
Kepolisian, Advokat, Kejaksaan, dan Pengadilan yang berpuncak pada Mahkamah Agung serta berakhir pada Lembaga Pemasyarakatan (Harahap, 2012).

Lembaga yang di maksud sebagai pelaksana fungsi penegakan hukum yang bertalian dengan penyelenggaraan Pilkada pada konteks kajian ini, khususnya yang sehubungan dengan kampanye prematur petahana, adalah Kepolisian, Kejaksaan, dan Komisi Pemberantasan Korupsi (KPK). Kepolisian dan Kejaksaan merupakan dua lembaga yang tidak dapat dipisahkan dalam proses penegakan hukum. Sedangkan untuk konteks pencegahan dan penegakan antikorupsi KPK juga melibatakan.

Keterlibatan lembaga penegak hukum dalam mengawasi-pelaksanaan kampanye prematur petahana, dan berbagai tindakan pemanfaatan jabatan petahana, untuk kepentingan elektoral dibenarkan karena adanya kewenangan aparat penegak hukum dalam hal ini sebagaimana diuraikan pada sub-bab sebelumnya. Misalkan, pada konteks pemanfaatan dana bansos penanganan Covid-19, Kepolisian bisa memiliki kewenangan penegakan sebagaimana diatur dalam Pasal 78 jo. Pasal 65 UU Penanggulangan Bencana. Sedangkan yang spesifik untuk Pilkada, keterlibatan Kepolisian dan Kejaksaan dapat merujuk ke Pasal 188 UU Pilkada dalam hal pemanfaatan keputusan oleh berbagai pejabat yang menguntungkan salah satu calon. Untuk konteks perbuatan melawan hukum, pemanfaatan jabatan yang mengarah pada kerugian negara akan menjadi objek pengawasan KPK. 


\subsection{Menuju Pengawasan Terintegrasi}

Berdasarkan

elaborasi

empat rezim pengawasan di atas, pola pengawasan bisa dibagun dengan menciptakan mekanisme pengoordinasian hubungan antarlembaga, kemudian mengintegrasikan fungsi pengawasan yang berada pada setiap bidang kelembagaan yang berbeda-berbeda (tetapi, beririsan dengan bidang kePilkada-an). Rangkaian ini disebut pengawasan terintegrasi. Kehadiran pengawasan terintegrasi pada dasarnya merupakan penegasan pelaksanaan kewenangan masingmasing lembaga yang ada untuk diharmonisasi pada fungsi pengawasan terhadap petahana di Pilkada.

Jika selama ini KPU, Bawaslu, dan DKPP mengenal forum koordinasi tripartit yang bersifat informal dengan tipologi complementary (pelengkap) dan tipe substitutive (pengganti) (Aditya Perdana, 2018), maka pengawasan terintegrasi akan diatur secara formal untuk memastikan keberlanjutan integrasi pengawasan, mengingat Pilkada merupakan agenda rutin dalam pengisian jabatan kepala daerah.

UU Pilkada nantinya harus memuat rumusan tentang tanggung jawab bersama lembaga-lembaga pengawasan yang ruang kerjanya berada di luar bidang ke-Pilkada-an (tetapi beririsan dengan ini) untuk terlibat secara aktif mengawasi petahana yang berpotensi melakukan kampanye prematur. Untuk relasi kelembagaan, hubungan lembaga pengawas yang terlibat dalam mekanisme pengawasan terintegrasi ini akan bersifat koordinasi, dengan tugas-tugas sebagai berikut. Pertama, membahas masalah aktual pengawasan Pilkada dan pelaksanaan kewenangan petahana. Kedua, memberikan masukan atas pelaksanaan masingmasing kewenangan pengawasan dan menyikapi setiap persoalan perkembangan berbagai aspek pelaksanaan Pilkada dan pemerintahan petahana. Ketiga, memfasilitasi hubungan kerja forum koordinasi pengawasanterintegrasidan hubungan antar lembaga atau instansi terkait. Keempat, memberikan rekomendasi sebagai bahan pertimbangan dalam pelaksanaan masing-masing kewenangan pengawasan terhadap hasil deteksi dini dan temuan dugaan pelanggaran.

Forum koordinasi pengawasan terintegrasi dalam menjalankan tugas di atas dikoordinatori oleh Bawaslu dengan keanggotaan yang terdiri dari perwakilan setiap rezim pengawasan untuk bidang-bidang di luar Pilkada. Ini terdiri dari perwakilan dari pengawasan pada rezim etik (DKPP), pemerintahan (APIP), pelayanan publik (Ombudsman), penegakan hukum (Kepolisian, Kejaksaan, dan KPK). Lagi pula, embrio pelibatan lembaga di luar rezim Pilkada telah mengada dalam norma UU Pilkada tentang Sentra Penegakan Hukum Terpadu misalnya; hal ini merujuk ke pelibatan Kepolisian, Kejaksaan, dan Bawaslu.

Pertimbangan memosisikan Bawaslu sebagai koordinator didasari atas dua alasan. Pertama, karena 
Bawaslu didesain sebagai salah satu unsur yang ada dalam sistem tata kelola penyelenggara Pilkada, khususnya dalam hal kepengawasan. Dalam hal ini, politik hukum UU Pilkada telah melembagakan Bawaslu sebagai pengawas penyelenggaraan Pilkada. Di samping itu, Bawaslu juga telah mempraktikkan koordinasi secara informal dalam pengawasan penyelenggaraan Pilkada bersama berbagai lembaga dari level pusat hingga daerah pada Pilkadapilkada sebelumnya. Kedua, karena pengawasan terintegrasi diarahkan pada perspektif ke-Pilkada-an sehingga Bawaslu menjadi tepat. Dalam hal ini, Penulis menyadari adanya ketidaksamaan persepsi secara kelembagaan dalam penegakan aturan-aturan yang berkaitan dengan praktik kampanye prematur petahana. Karenanya, Bawaslu menjadi lembaga yang lebih memadai untuk menjaga konsistensi pengawasan dalam ranah, perspektif, atau konteks ke-Pilkada-an. Walau begitu, pemaknaan Bawaslu sebagai koordinator pengawasan terintegrasi tidak merujuk pada sifat relasi antar-lembaga yang struktural, namun koordinator dalam rangka mengoptimalkan masing-masing kewenangan yang dimiliki tiap-tiap lembaga yang terlibat ketika praktik kampanye prematur terjadi.

Format keterlibatan rezim-rezim, namun demikian, dapat berubah berdasarkan kondisi dan kebutuhan. Misalnya, mekanisme pengawasan terintegrasi dapat melibatkan Pusat Pelaporan dan Analisis Transaksi Keuangan ketika perlu untuk mengetahui aliran dana petahana.

Koordinasi pengawasan ini akan dilaksanakan secara periodik yang temporer, yang ini dapat dimulai pada masa enam bulan sebelum tanggal penetapan pasangan calon sampai dengan tanggal penetapan calon. Pilihan waktu ini mengacu pada rumusan Pasal 71 ayat (2) UU Pilkada. Hal ini bertujuan agar tindakan koordinasi sejalan dengan politik hukum pengawasan petahana yang ada dalam UU Pilkada.

\section{Simpulan}

Penelitian ini menyimpulkan dua hal. Pertama, kampanye prematur petahana tidak diatur secara pasti dan tegas dalam UU Pilkada sehingga tidak ada juga kepastian lembaga pegawasnya. Walau begitu, bila kampanye prematur dipertimbangkan atas dasar tujuan atau akibat yang ditimbulkannya, yaitu meyakinkan dan/atau memobilisasi pemilih, maka kampanye prematur petahana dapat menjadiobjek pengawasanyang aturan normatifnya tersebar di berbagai undang-undang yang berbeda-beda ruang lingkup pemberlakuannya. Ini membuat terjadinya ambiguitas lembaga pengawasan, apalagi koordinasi antar-lembaga yang terlibat adalah buruk sehingga kampanye prematur petahana belum dapat diawasi secara memadai. Kedua, problematik banyaknya aturan normatif yang dapat "menyasar" tindakan kampanye prematur petahana dan ambiguitas lembaga pengawas untuk kampanye prematur petahana harus dituntaskan.

Tawaran dalam penelitian ini adalah menciptakan forum koordinasi pengawasan untuk setiap lembagalembaga yang terlibat, yang lembaga- 
lembaga dimaksud dapat mengawasi kampanye prematur sesuai dengan konteks peraturannya. Forum koordinasi ini merefleksikan apa yang kami maksud dengan pengawasan terintegrasi yang menjadi wadah koordinasi lembaga pengawasan antar-rezim. Namun demikian, disadari bahwa tawaran ini berprespektif institusionalisme, yang perspektif ini sesungguhnya hanya satu dari model-model alternatif yang dapat dikonstruksikan untuk mengawasi kampanye prematur petahana. Oleh sebab itu, penelitian lebih lanjut sehubungan dengan pengawasan terhadap kampanye prematur, baik oleh petahana maupun non-petahana, akan selalu menarik untuk dilakukan pada masa mendatang. 


\section{DAFTAR PUSTAKA}

\section{Buku}

Bawaslu. (2020). Indeks Kerawanan Pemilu (IKP) Pilkada Serentak 2020, Jakarta, Bawaslu.

E. Rice Ronald \& J. Paisley William. (1981). Public Communication Campaigns, New York, SAGE Publications.

, \& K. Atkin Charles. (2013). Public Communication Campaigns, Edisi Keempat, California, SAGE Publications.

Harahap Yahya. (2021). Pembahasan Permasalahan dan Penerapan KUHAP, Jakarta, Grafika.

HR. Ridwan. (2016) Hukum Administrasi Negara, cetakan kedua belas, Jakarta, Rajagrafindo Persada.

Orozco Jesus \& Henriquez. (2010). (Eds). Electoral Justice: The International IDEA Handbook, International IDEA. Stockholm.

Poeltje Van. (1953). Pengantar Umum Ilmu Pemerintahan, Diterjemahkan oleh

B.Mang Reng Say,N.V. Soeroengan Petjenongan, Djakarta.

Tjandra Riawan. (2014). Hukum Keuangan Negara. Jakarta, Grasindo.

Sembiring Reynaldo. (2014). (Eds). Anotasi Undang-Undang Nomor 32 Tahun 2009 tentang Perlindungan dan Pengelolaan Lingkungan Hidup, Indonesia, Jakarta, Center for Environmental.

Jurnaidi Veri, Agustyati Khoirunnisa, \& Hatomo Ibnu Setyo. (2013). Potret Keterbukaan dan Partisipasi Publik dalam Penyusunan Undang-Undang Nomor 8 Tahun 2012 tentang Pemilihan Umum Anggota DPR, DPD, dan $D P R D$, Jakarta, Yayasan Perludem

Syafrudin, Ateng. (1976). Pengaturan Koordinasi Pemerintahan di Daerah. Bandung. Penerbit Tarsito

\section{Jurnal}

Apori Nkansah Lidya. (2016). Dispute Resolution and Elctoral Justice in Africa: the Way Forward, Africa Development, Vol.41, No.2 .

Ashworth Scott. (2006). Campaign Finance and Voter Welfare with Entrenched Incumbents, American Political Science Review, Vol. 100, No. 1.

Siregar Fritz Edward. (2019). Pilihan Transformasi Badan Peradilan Khusus Pemilu", dalam Ahsanul Minan (ed.), Serial Evaluasi Penyelenggaraan Pemilu Serentak 2019. Perihal Penegakan Hukum Pemilu, Jakarta, Bawaslu.

Fatimah Siti. (2018). Kampanye sebagai Komunikasi Politik: Esensi dan Strategi dalam Pemilu, Resolusi, Vol.1, No.1, Juni 2018.

Sanyoto. (2008). Penegakan Hukum Di Indonesia. Jurnal Dinamika Hukum Vol. 8 No. 3 September 2008 
Schmitt Beck Rudiger \& M. Farrel David. (2002). Studying Political Campaigns and Their Effects, dalam David. M. Farrel dan Rudiger Schmitt-Beck (Eds), Do Political Campaigns Matter? Campaign Effects in Elections and Referendums, New York, Routledge. 2002.

Syarwani Arif. (2016). Pentingnya Penegakan Kode Etik Peserta Pemilu, Jurnal Jurnal Etika \& Pemilu Vol. 2, Nomor 2.

Tuccinardi Domenico. (2011). Electoral Justice as an Important Form of Conflict Prevention", dalam Summary Report of Thematic Workshop on Elections, Violence and Conflict Prevention, Workshop diadakan oleh European Commission, United Nations Development Program, dan International Institute for Democracy and Election Assistance di Montjuic Castle, Barcelona, Spanyol, 20-24 Juni.

Marwata Alexander. (2017). Membangun Independensi Aparat Pengawas, dalam Majalah Warta Pengawasan Vol.XXIV/Nomor 4/Tahun 2017.

\section{Media Online dan Opini}

Perdana Aditya (2018). Tripartit Penyelenggara Pemilu, Harian Kompas, 19 September.

Nugraheny Dian Erika. (2020). Kepala Daerah Salahgunakan Bansos Covid, Komisi

II: Kejahatan yang Tak Bisa Dibiarkan, diakses dari https://nasional. kompas .com/read/2020/05/07/15230551/kepala-daerah- salahgunakanbansos-covid-19- komisi-ii-kejahatan-yang-tak-bisa? page=all, pada 10 Juli 2020.

Awalani Aji. (2020). Curi Start Kampanye Lewat Pertemuan, ASN di Gunungkidul Dianggap Langgar Aturan, diakses dari http://gunungkidul.sorot. co/berita-100968-curi-start-kampanye-lewat-pertemuan-asn-digunungkidul-dianggap-langgar-aturan.html, pada 28 Juli 2020.

Akbar Jay. (2018). Antisipasi Korupsi Dana Bansos dan Hibah dalam Pilkada 2018 diakses dari https://tirto.id/cEm3 pada 26 Juli 2020. 
120 Jurnal Adhyasta Pemilu 